\title{
Przedoperacyjne wartości progów słyszenia jako kryterium kwalifikacji do wszczepienia implantu ślimakowego
}

\section{Preoperative hearing thresholds as a selection criterion for cochlear implantation}

\author{
Anna Piotrowska ${ }^{1,2}$, Artur Lorens ${ }^{1,2}$, Jolanta Serafin-Jóźwiak ${ }^{1,2}$, Henryk Skarżyński ${ }^{1,2}$ \\ ${ }^{1}$ Instytut Fizjologii i Patologii Słuchu, ul. Zgrupowania AK „Kampinos” 1, 01-943 Warszawa \\ ${ }^{2}$ Światowe Centrum Słuchu, ul. Mokra 17, Kajetany, 05-830 Nadarzyn
}

Adres autora: Anna Piotrowska, Światowe Centrum Słuchu, ul. Mokra 17, Kajetany, 05-830 Nadarzyn; e-mail: a.piotrowska@ifps.org.pl

\section{Streszczenie}

Wstęp: Wprowadzenie do praktyki klinicznej implantów ślimakowych stworzyło nowe możliwości lepszego słyszenia i komunikacji językowej szerokiej grupie pacjentów. Stymulacja elektryczna zakończeń nerwu słuchowego przez implant ślimakowy stanowi, w świetle aktualnej wiedzy, skuteczną formę protezowania wielu wad słuchu. Wskazania do stosowania implantu ślimakowego określane są za pomocą kryteriów doboru i selekcji pacjentów. Kryteria te zmieniały się znacząco od czasu wprowadzenia tej metody leczenia do praktyki klinicznej. Jednym z kryteriów kwalifikacji jest przedoperacyjna wartość progów słyszenia.

Cel: W pracy przedstawiono wartości przedoperacyjnych progów słyszenia u pacjentów kwalifikowanych do wszczepienia implantu ślimakowego.

Wyniki: Audiologiczne kryteria kwalifikacji do wszczepienia implantu ślimakowego ewaluowały od obustronnej głuchoty (>110 dB HL) na początku lat 80, poprzez znaczny niedosłuch (>70 dB HL) w latach 90., do aktualnego kryterium, które pozwala na stosowanie tej metody leczenia u pacjentów z częściową głuchotą.

Wnioski: Rosnąca liczba pacjentów z częściową głuchotą korzystających z implantu ślimakowego świadczy o rozszerzeniu zakresu wskazań do stosowania stymulacji elektrycznej oraz potwierdza możliwość niesienia efektywnej pomocy terapeutycznej coraz większej grupie osób.

Słowa kluczowe: implanty ślimakowe • częściowa głuchota • niedosłuch • progi słyszenia

Abstract

Introduction: Introduction of cochlear implants to the clinical practice has created new possibilities for better hearing and speech communication in a wide group of patients. According to the present knowledge, electric stimulation of the auditory nerve with cochlear implant is an effective form of hearing restoration. Indications for the cochlear implantation are determined with the criteria of choice and selection of patients. These criteria has changed significantly, since the method was introduced to the clinical practice. Preoperative hearing thresholds are considered to be one of the selection criteria.

Aim: In the study the values of preoperative hearing levels in patients qualified for the cochlear implantation are presented.

Results: Criteria of audiological qualification for the cochlear implantation have evaluated from bilateral deafness $(>110 \mathrm{~dB}$ $\mathrm{HL}$ ) at the early 80 ., through profound hearing impairment (>70 dB HL) in the 90 ., and to the present criteria which enable to use this procedure of treatment in patients with partial deafness.

Conclusions: A growing number of patients with partial deafness who are using the cochlear implants proves that the scope of indications for the electric stimulation has widen and more patients can benefit from the method.

Key words: cochlear implants • partial deafness • hearing loss • hearing thresholds 


\section{Wstęp}

Implanty ślimakowe są jedną z dostępnych obecnie, stosowanych klinicznie protez słuchowych. Stymulacja elektryczna zakończeń nerwu słuchowego przez implant ślimakowy stanowi, w świetle aktualnej wiedzy, skuteczną formę protezowania wielu wad słuchu.

Pierwszy na świecie program leczenia głuchoty za pomocą implantów ślimakowych rozpoczął w 1972 r. w Stanach Zjednoczonych William House [House i wsp. 1973]. Wykorzystywał on, pierwszy produkowany seryjnie, jednokanałowy system 3M. W latach 1972-1985 implant 3M został wszczepiony ponad 1000 pacjentów. Implanty te niestety okazały się bardzo awaryjne i zostały wkrótce wycofane z użytku klinicznego. Podobny program w Europie rozpoczął w 1973 r. C.H. Chouard [Chouard i wsp. 1976] w Paryżu, a K. Burian w 1975 r. w Wiedniu [Burian i wsp. 1986].

Program leczenia całkowitej głuchoty i głębokich niedosłuchów z wykorzystaniem implantów ślimakowych został zapoczątkowany w Polsce przez H. Skarżyńskiego w roku 1992 [Skarżyński i wsp. 1993; 1993a].

Wskazania do stosowania implantu ślimakowego określane są za pomocą kryteriów doboru i selekcji pacjentów. Kryteria te zmieniały się znacząco od czasu wprowadzenia tej metody leczenia do praktyki klinicznej [Skarżyński i wsp. 2005]

\section{Wartości przedoperacyjnych progów słyszenia u pacjentów kwalifikowanych do wszczepienia implantu ślimakowego}

Zgodnie z początkowymi wskazaniami klinicznymi wszczepienie implantu ślimakowego rozważano jedynie w przypadku całkowitej głuchoty u osoby dorosłej, a uzyskanie jakichkolwiek reakcji akustycznych w wyniku stymulacji elektrycznej uznawano za sukces [Burian i wsp. 1986]. Pierwszych kilkuset dorosłych pacjentów korzystało z implantu jednokanałowego, który umożliwiał jedynie odbiór podstawowych wrażeń dźwiękowych. W jednym na dwadzieścia przypadków umożliwiał, w ograniczonym stopniu, rozumienie mowy [House i wsp. 1973]. Wraz z wprowadzaniem nowych rozwiązań technologicznych, w postaci systemów wielokanałowych, populacja użytkowników implantu ślimakowego na świecie znacząco i systematycznie wzrastała [Michelson i wsp. 1981]. Wyniki osiągane przez pacjentów z implantami były coraz lepsze, a liczne publikacje i doniesienia potwierdzały rozumienie mowy w zestawach otwartych [Helms i wsp. 1991; Kiefer i wsp. 1998; Skarżyński i wsp. 1993]. Na tej podstawie zaproponowano wszczepianie implantów dzieciom oraz pacjentom, którzy pomimo możliwości percepcji dźwięku w aparatach słuchowych nie uzyskiwali satysfakcjonującego poziomu rozumienia mowy [Kiefer i wsp. 1998].

Grupa z Colorado przeanalizowała wyniki badań audiometrycznych 40 pacjentów implantowanych w latach 1985-1988 w Colorado Ear Clinic [Boggess i wsp. 1989]. Do wszczepienia implantu ślimakowego kwalifikowano pacjentów, u których występowały reakcje słuchowe dla przynajmniej jednej częstotliwości w zakresie wydolności audiometru Madsen OB 822 z zestawem słuchawkowym TDH-39. Maksymalny poziom na wyjściu dla

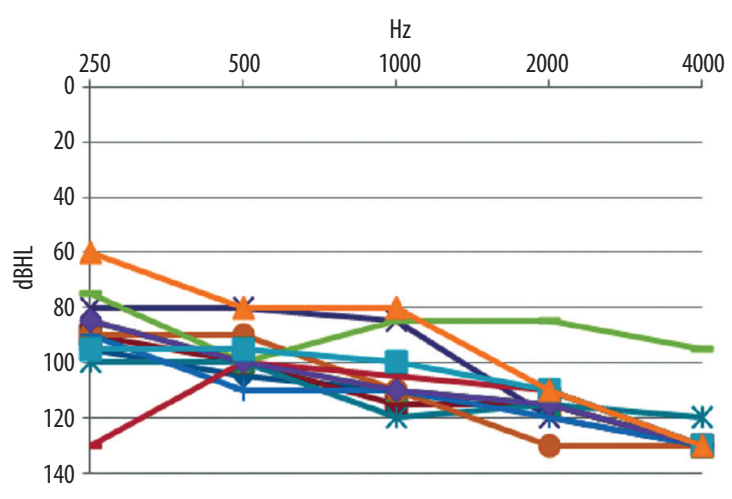

Rycina 1. Indywidualne przedoperacyjne wartości progów słyszenia w uchu implantowanym analizowane w pracy Boggesa; (progom słyszenia przekraczającym zakres wydolności audiometru przypisano wartości $130 \mathrm{~dB} \mathrm{HL}$ ) [Boggess i wsp. 1989]

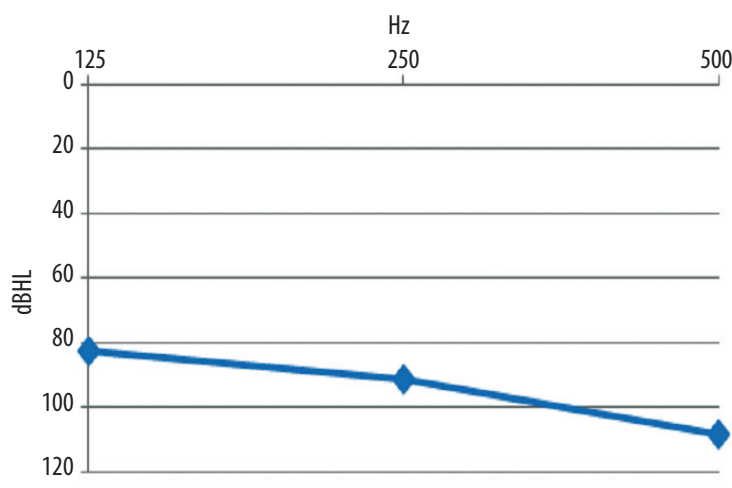

Rycina 2. Uśrednione przedoperacyjne wartości progów słyszenia w uchu kwalifikowanym do wszczepienia implantu ślimakowego w grupie dzieci i dorosłych [Skarżyński i wsp. 2002]

poszczególnych częstotliwości wynosił: $250 \mathrm{~Hz}-105 \mathrm{~dB}$ HL, $500 \mathrm{~Hz}-115 \mathrm{~dB}$ HL, $1000 \mathrm{~Hz}-120 \mathrm{~dB} \mathrm{HL}, 2000 \mathrm{~Hz}$ - $115 \mathrm{~dB} \mathrm{HL}, 4000 \mathrm{~Hz}-120 \mathrm{~dB}$ HL. Indywidualne przedoperacyjne wartości progów słyszenia w uchu kwalifikowanym do wszczepienia w tej grupie przedstawia Rycina 1.

Zastosowanie implantów u pacjentów z takim niedosłuchem, który pozwalał jedynie na bardzo ograniczone rozumienie mowy w aparatach słuchowych, stanowiło kolejny krok w kierunku rozszerzenia kryteriów kwalifikacji [Kiefer i wsp. 1998; Zeng i wsp. 2004]. Po wszczepieniu implantu ślimakowego pacjenci ci uzyskują obecnie możliwość komunikacji na drodze słuchowej, bez konieczności odczytywania mowy z ust [Anderson i wsp. 2004; Anderson i wsp. 2004a; Vermeire i wsp. 2008].

Skarżyński i wsp. przedstawili grupę 26 pacjentów (19 dorosłych, 7 dzieci) [Skarżyński i wsp. 2002]. Uśrednione przedoperacyjne wartości progów słyszenia dla 125, 250, $500 \mathrm{~Hz}$ w uchu kwalifikowanym do wszczepienia implantu ślimakowego wyniosły odpowiednio 82,9, 91,5, 108,3 dB HL (Rycina 2.).

Kiefer [Kiefer i wsp. 1998] zaproponował rozszerzone kryteria kwalifikując do wszczepienia implantu ślimako- 


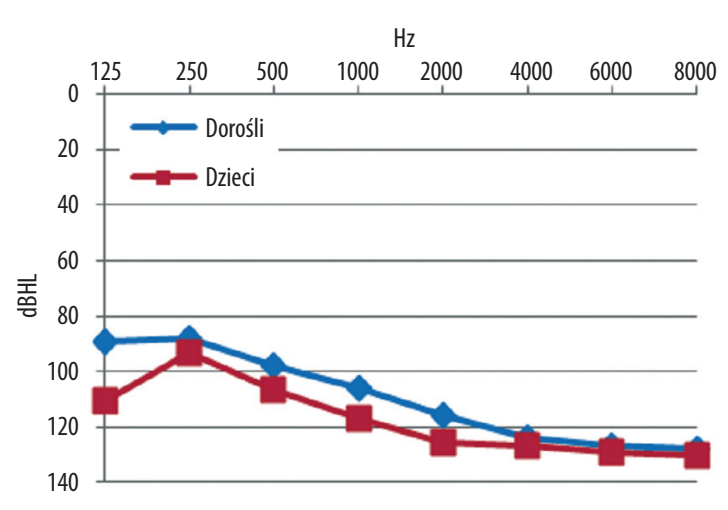

Rycina 3. Uśrednione, w grupie dzieci i dorosłych, wartości progów styszenia w uchu kwalifikowanym do wszczepienia implantu ślimakowego [Kiefer i wsp. 1998]

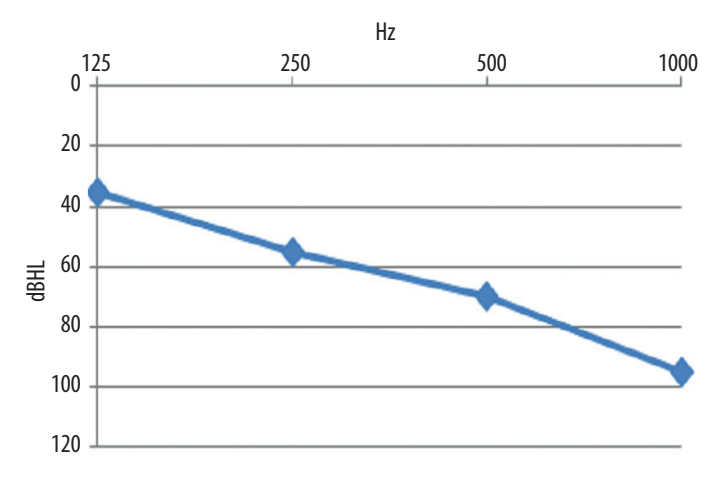

Rycina 4. Wartości progów słyszenia w uchu zakwalifikowanym do wszczepienia implantu ślimakowego [Ilberg i wsp. 1999]

wego osoby dorosłe, których wartości progów słyszenia w uchu kwalifikowanym do implantacji nie przekraczały $110 \mathrm{~dB}$ HL przynajmniej dla dwóch częstotliwości z przedziału 250-4000 Hz oraz dzieci - jak wyżej lub $\leq 100 \mathrm{~dB}$ HL zmierzone przynajmniej na jednej częstotliwości z przedziału 500-4000 Hz. W grupie dzieci, jeśli nie uzyskiwano wiarygodnych wyników przedoperacyjnych w audiometrii tonalnej, wykonywano badanie potencjałów wywołanych pnia mózgu, z zastosowaniem bodźców specyficznych częstotliwościowo; średnia wartość progów słyszenia w uchu implantowanym w przedziale $250-4000 \mathrm{~Hz}$ dla grupy dorosłych wynosiła $106 \mathrm{~dB}$ HL, dla dzieci - $114 \mathrm{~dB}$ HL. Z pracy nie wynika jednak jasno, jak w obliczeniu średniego progu słyszenia autorzy potraktowali progi, których wartości przekraczały zakres wydolności audiometru (tzw. progi niemierzalne, NM) dla poszczególnych częstotliwości. W takim przypadku istnieją bowiem co najmniej dwie możliwości obliczenia wyników, opisane kilka lat później w literaturze [James i wsp. 2005]. Można progi niemierzalne (NM) usunąć i nie brać ich pod uwagę w obliczaniu średniej lub zamienić wartość NM na wartość maksymalnego ciśnienia akustycznego w zakresie wydolności danego audiometru (typowo 120 lub $130 \mathrm{~dB}$ HL). W zależności od przyjętej metody postępowania otrzymuje się różne wyniki średniego progu, które w obydwu przypadkach są zaniżone. Wartości przedoperacyjnych uśrednionych progów słyszenia dla dorosłych i dzieci przedstawiono na Rycinie 3.

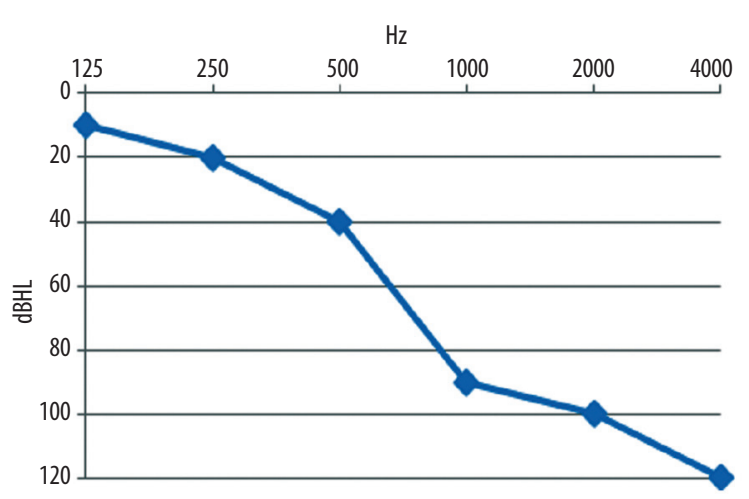

Rycina 5. Wartości progów słyszenia w uchu kwalifikowanym do wszczepienia implantu ślimakowego u pierwszej operowanej pacjentki z częściową głuchotą [Skarżyński i wsp. 2003]

Po przeanalizowaniu wyników rozumienia mowy w implancie w badanej grupie zaproponowano dalsze rozszerzenie kryteriów kwalifikacji do wszczepienia implantu ślimakowego, umożliwiając kwalifikowanie do operacji pacjentów, u których w badaniu przedoperacyjnym stwierdza się progi audiometryczne na poziomie nieprzekraczającym: 60, 70, 80, 90, 100, $110 \mathrm{~dB}$ HL odpowiednio dla częstotliwości 125, 250, 500, 1000, 2000, $4000 \mathrm{~Hz}$.

Dalsze złagodzenie kryteriów kwalifikacji do wszczepienia implantu ślimakowego $\mathrm{z}$ jednoczesnym potwierdzeniem zachowania czułości słuchu zostało przedstawione w pracy von Ilberga, na przykładzie wyników pacjenta dorosłego zaimplantowanego systemem Med-El C40+, z wprowadzeniem 20 mm elektrody [Ilberg i wsp. 1999]. Przedoperacyjne progi słyszenia w uchu implantowanym wynosiły: 35, 55, 70, 95 dB HL odpowiednio dla 125, 250, 500, 1000 $\mathrm{Hz}$ (Rycina 4.). Takie wartości progów audiometrycznych do tej pory nie były brane pod uwagę jako kwalifikujące do implantacji. Wyniki pooperacyjne przedstawiały się następująco: 50, 75, 90, $100 \mathrm{~dB}$ HL odpowiednio dla 125, 250, 500, $1000 \mathrm{~Hz}$. Zachowanie czułości słuchu po operacji określono jako częściowe. Jednak zachowanie słuchu w zakresie częstotliwości $125-500 \mathrm{~Hz}$ pozwoliło, po raz pierwszy, na skuteczne zastosowanie stymulacji elektryczno-akustycznej, tj. implantu ślimakowego i aparatu słuchowego w tym samym uchu. Łączona stymulacja może poprawić jakość słyszenia oraz zwiększyć stopień rozumienia mowy w porównaniu do wyników osiąganych z zastosowaniem tylko stymulacji akustycznej (aparatu słuchowego) lub tylko stymulacji elektrycznej (implantu).

W roku 2003 Skarżyński i wsp. przedstawili wyniki zachowania czułości słuchu u pacjentki $\mathrm{z}$ „częściową głuchotą" [Skarżyński i wsp. 2003]. Jako częściowa głuchota zdefiniowano progi słyszenia 0-55 dB HL w zakresie częstotliwości 125-500 Hz oraz $>70 \mathrm{~dB}$ HL w zakresie częstotliwości powyżej $500 \mathrm{~Hz}$ (Rycina 5.) Było to bardzo nowatorskie, jak na ówczesne czasy, rozwiązanie terapeutyczne nazwane nową metoda leczenia częściowej głuchoty (Partial Deafness Treatment - PDT). Operacja przeprowadzona w Instytucie Fizjologii i Patologii Słuchu w Warszawie, w lipcu 2002 roku była pierwszą w świecie operacja wszczepienia implantu ślimakowego do ucha ze słuchem prawidłowym w zakresie niskich częstotliwości. Pacjenci 


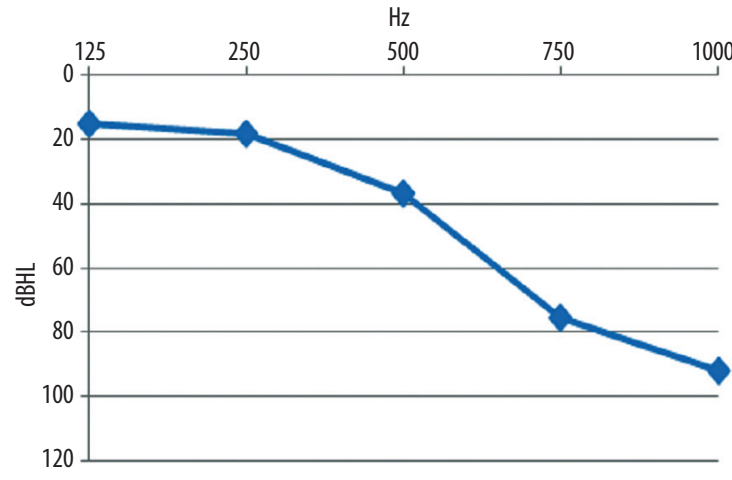

Rycina 6. Uśrednione, w grupie pacjentów dorosłych, wartości progów styszenia w uchu zakwalifikowanym do wszczepienia implantu ślimakowego [Skarżyński i wsp. 2006]

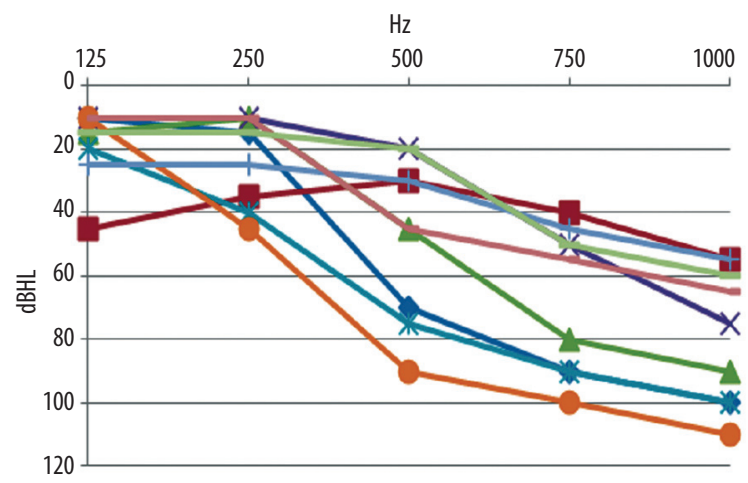

Rycina 7. Indywidualne przedoperacyjne wartości progów słyszenia w uchu zakwalifikowanym do wszczepienia implantu ślimakowego w grupie dzieci [Skarżyński i wsp. 2007]

z częściową głuchotą nie byli dotychczas kwalifikowani do wszczepienia implantu ślimakowego, ponieważ istniała obawa, że podczas operacji zniszczony zostanie sprawnie funkcjonujący fragment ślimaka.

Pierwszą w świecie tego typu operację u dziecka z częściową głuchotą wykonał H. Skarżyński 27 września 2004 roku [Skarżyński i wsp. 2007]. Badania prowadzone w ostatnich latach w Instytucie Fizjologii i Patologii Słuchu wykazały, że zastosowanie stymulacji elektryczno-akustycznej za pośrednictwem implantu ślimakowego, przywracającej słyszenie wysokich i średnich częstotliwości przy jednoczesnym zachowaniu czułości słuchu pacjenta dla niskich częstotliwości, stanowi skuteczną metodę terapii dla znacznej grupy pacjentów [Lorens i wsp. 2008; Skarżyński i wsp. 2002; 2004; 2006; 2007].

W kolejnych latach zaproponowane kryterium kwalifikacji stosowano w IFPS w grupie pacjentów dorosłych [Skarżyński i wsp. 2006; 2007a] oraz dzieci [Skarżyński i wsp. 2007]. Na Rycinach 6 i 7 przedstawiono wartości progów słyszenia w uchu kwalifikowanym do wszczepienia implantu ślimakowego.

W odpowiedzi na zaproponowane przez Skarżyńskiego kolejne rozszerzenie wskazań do implantacji, na podstawie
$\mathrm{Hz}$

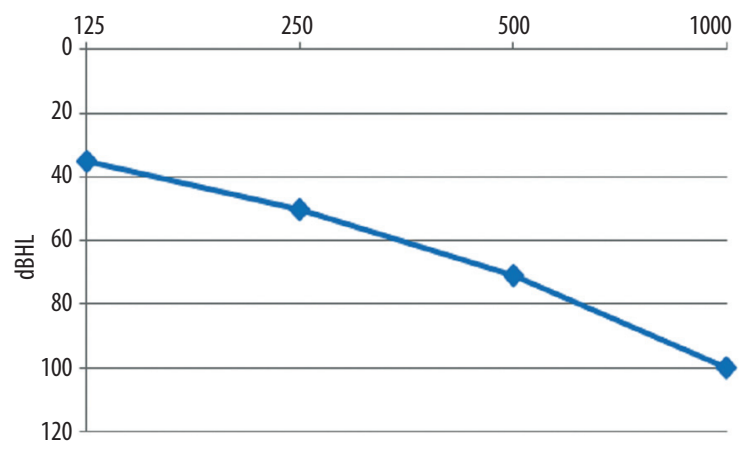

Rycina 8. Średnie dla grupy wartości progów słyszenia w uchu zakwalifikowanym do wszczepienia implantu ślimakowego [Kiefer i wsp. 2004]

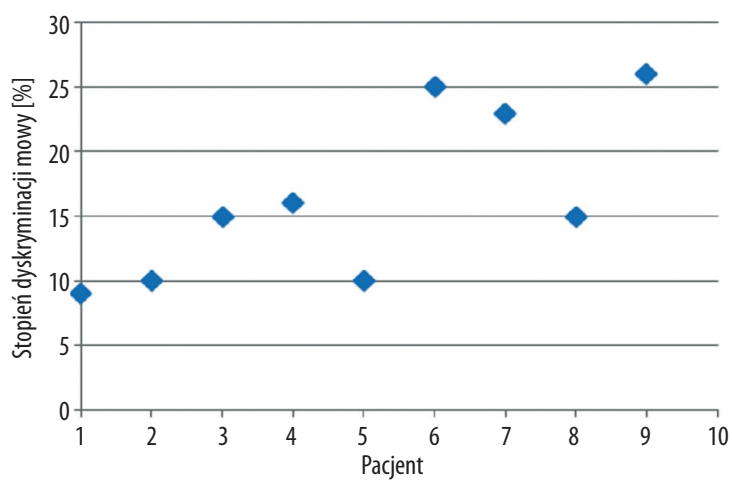

Rycina 9. Wyniki rozumienia słów jednosylabowych w badaniu z wolnego pola w aparacie słuchowym na uchu kwalifikowanym do wszczepienia implantu ślimakowego; (poziom prezentacji bodźca $40 \mathrm{~dB} \mathrm{SL}$ ) [Gantz i wsp. 2004]

udokumentowanego zachowania słuchu w zakresie niskich częstotliwości, w roku 2004 przedstawiono wyniki zachowania czułości słuchu na materiale klinik uniwersyteckich z Frankfurtu i Wiednia. Kiefer i wsp. przebadali grupe 14 pacjentów, u których przedoperacyjne wartości progu słyszenia zawierały się w przedziale $20-60 \mathrm{~dB}$ HL przynajmniej dla dwóch częstotliwości z zakresu $125-500 \mathrm{~Hz}$ [Kiefer i wsp. 2004]. Dla częstotliwości $250 \mathrm{~Hz}$ u 3 pacjentów w badaniu przedoperacyjnym uzyskano progi w uchu kwalifikowanym do implantacji $\leq 30 \mathrm{~dB} H \mathrm{HL}$, u 2 w przedziale $30-50 \mathrm{~dB} H \mathrm{HL}, \mathrm{u}$ pozostałych 9 pacjentów $\leq 50 \mathrm{~dB}$ HL. Średnia wartość progów słyszenia w uchu kwalifikowanym do operacji dla grupy wynosiła $61 \mathrm{~dB} \mathrm{HL}$ w przedziale 125-1000 Hz. Średnie wartości progów audiometrycznych w uchu implantowanym przed wszczepieniem implantu ślimakowego przedstawiono na Rycinie 8.

W badaniach przeprowadzonych przez Gantza [Gantz i wsp. 2004] do wszczepienia implantu ślimakowego z krótką elektrodą (6 i $10 \mathrm{~mm}$ ), jako kryterium kwalifikacji oprócz oceny audiometrycznych progów słyszenia mierzono poziom stopnia dyskryminacji słów jednosylabowych w badaniu z wolnego pola w aparacie słuchowym. Wyniki testu słownego przedstawione są na Rycinie 9. 


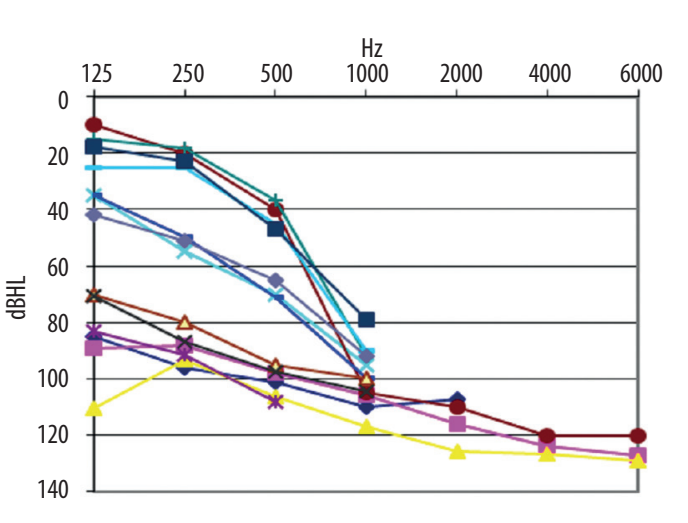

\section{Podsumowanie}

Na podstawie wybranych danych literaturowych widzimy, że audiologiczne kryteria kwalifikacji do wszczepienia implantu ślimakowego ewaluowały od obustronnej głuchoty $(>110$ dB HL) na początku lat 80., poprzez znaczny niedosłuch (>70 dB HL) w latach 90., do aktualnego kryterium, które pozwala na stosowanie tej metody leczenia u pacjentów z częściową głuchotą. Z tego faktu wynika, iż obecnie wielu pacjentów kwalifikowanych do wszczepienia implantu ślimakowego posiada tzw. wartości progów słyszenia, umożliwiające ograniczone rozumienie mowy w aparatach słuchowych [Lorens i wsp. 2012; Skarżyński i wsp. 2003a; 2012].

Na Rycinie 10 przedstawiono wybrane progi słyszenia przedstawiające wartości przedoperacyjnej czułości słuchu w uchu kwalifikowanym do wszczepienia implantu (wartości średnie). Wyniki wpisują się wyraźnie w trzy grupy: grupa I [Boggess i wsp. 1989; Kiefer i wsp. 1998; Skarżyński

\section{Piśmiennictwo:}

1. Anderson I., Weichbold V., D’Haese P.: Three-year follow up of children with open-set speech recognition who use the MED-EL cochlear implant system. Cochlear Implants International, 2004; 5(2): 45-57

2. Anderson I., Weichbold V., D'Haese P.S. i wsp.: Cochlear implantation in children under the age of two - what do the outcomes show us? Int J Pediatr Otorhinolaryngol, 2004a; 68(4): $425-31$

3. Baumgartner W.D., Jappel A., Morera C. i wsp.: Outcomes in adults implanted with the Flex electrode. Acta Otolaryngol, 2007; 127: 579-86 after cochlear implantation. Laryngoscope, 1989; 99: 1002-5

5. Burian K., Hochamir-Desoyer I.J., Eisenwort B.: The Vienna cochlear implant program. Otolaryngol Clin North Am, 1986; $19 ; 313-28$

6. Chouard C.H., MacLeod P.: Implantation of multiple intracochlear electrodes for rehabilitation of total deafness: preliminary report. Laryngoscope, 1976; 86: 1743-51

7. Di Nardo W., Cantore I., Melillo P. i wsp.: Residual hearing in cochlear implant patients. Eur Arch Otorhinolaryngol, 2007; 264: 855-60

8. Gantz B.J., Turner C.W.: Combining Acoustic and Electrical Speech Processing: Iowa/Nucleus Hybrid Implant. Acta Otolaryngol, 2004; 124: 344-47
4. Boggess W.J., Baker J.E., Balkany T.J.: Loss of residual hearing
Rycina 10. Przedoperacyjne wartości progów styszenia w uchu kwalifikowanym do wszczepienia implantu ślimakowego wg różnych autorów

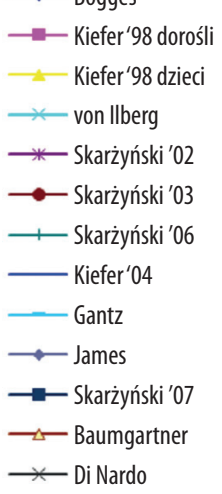

i wsp. 2002] - najwyższe spośród analizowanych progi słyszenia, 80-130 dB HL; grupa III [Gantz i wsp. 2005; Skarżyński i wsp. 2003; 2006; 2007; 2007a; Baumgartner i wsp. 2007; Di Nardo i wsp. 2007] - najmniejsze wartości progów słyszenia, dla częstotliwości 125, $250 \mathrm{~Hz}$ słuch w granicach normy, grupa II [James i wsp. 2005; Kiefer i wsp. 2004; Ilberg i wsp. 1999] - progi słyszenia w przedziale 35-70 dB HL.

W podsumowaniu należy stwierdzić, że w ciągu minionych lat dokonało się wiele przemian w dziedzinie implantów ślimakowych. Zmieniły się kryteria kwalifikacji do stosowania tej metody terapii. Od roku 2002, tj. od 10 roku realizacji Programu Implantów Ślimakowych w Instytucie Fizjologii i Patologii Słuchu, obserwujemy stały wzrost liczby operowanych pacjentów z częściową głuchotą. Rosnąca liczba tych pacjentów świadczy o rozszerzeniu zakresu wskazań do stosowania stymulacji elektrycznej oraz potwierdza możliwość niesienia efektywnej pomocy terapeutycznej coraz większej grupie osób.
9. Gantz B.J., Turner C., Gfeller K.E., Lowder M.W.: Preservation of hearing in cochlear implant surgery: advantages of combined electrical and acoustical speech processing. Laryngoscope, 2005; 115: 796-802

10. Helms J., Müller J., Schön F. i wsp.: Evaluation of performance with the COMBI40 cochlear implant in adults: a multicentric clinical study. ORL J Otorhinolaryngol Relat Spec, 1997; 59(1): 23-35

11. House W.F., Urban J.: Long term results of electrode implantation and electronic stimulation of the cochlea in man. Ann Otol Rhinol Laryngol, 1973; 82: 504-17

12. James C., Albegger K., Battmer R. i wsp.: Preservation of residual hearing with cochlear implantation: how and why. Acta Otolaryngol, 2005; 125(5): 481-91

13. Kiefer J., von Ilberg C., Reimer B. i wsp.: Results of cochlear implantation in patients with severe to profound hearing loss - implications for patients selection. Audiology, 1998; 37 : 382-95

14. Kiefer J., Gstoettner W., Baumgartner W. i wsp.: Conservation of Low-frequency Hearing in Cochlear Implantation. Acta Otolaryngol, 2004; 124: 272-80

15. Lorens A., Polak M., Piotrowska A., Skarżyński H.: Outcomes of treatment of partial deafness with cochlear implantation: a DUET study. Laryngoscope, 2008; 118(2): 288-94 
16. Lorens A., Zgoda M., Skarżyński H.: A new audio processor for combined electric and acoustic stimulation for the treatment of partial deafness. Acta Otolaryngol., 2012; 132(7): 739-50

17. Michelson R.P., Schindler R.A.: Multichannel cochlear implant preliminary results in man. Laryngoscope, 1981; 91(1): 38-42

18. Skarżyński H., Janczewski G., Niemczyk K., Geremek A.: Cochlear implants: state of knowledge, prospects, indications for implantation. Otolaryngol Pol, 1993; 47(5): 444-51

19. Skarżyński H., Janczewski G., Niemczyk K. i wsp.: First cochlear implant in Poland. Otolaryngol Pol, 1993a; 47(5): 427-34

20. Skarżyński H., Lorens A., D’Haese P. i wsp.: Preservation of residual hearing in children and post-lingually deafened adults after cochlear implantation: an initial study. ORL, 2002; 64: 247-53

21. Skarżyński H., Lorens A., Piotrowska A.: A new method of partial deafness treatment. Med Sci Monit, 2003; 9(4): CS26-30

22. Skarżyński H., Piotrowska A., Lorens A. i wsp.: Applications of electric-acoustic stimulation in patients with profound hearing loss: Case study. International Congress Series. Proceedings of the XVII World Congress of the International federation of Oto-Rhino-Laryngological Societies (IFOS), 2003a; 1240: 291-95

23. Skarżyński H., Lorens A., Piotrowska A.: Preservation of low-frequency hearing in partial deafness cochlear implantation. Extended Abstracts from the VIII International Cochlear Implant Conference, Indianapolis, USA: International Congress Series, 2004; 1273: 239-42
24. Skarżyński H, Lorens A, Piotrowska A.: Wszczepy ślimakowe. Sliwinska-Kowalska M. Audiologia Kliniczna. Łódź. Mediton: 2005

25. Skarżyński H., Lorens A., Piotrowska A., Anderson I.: Partial deafness cochlear implantation provides benefit to a new population of individuals with hearing loss. Acta Otolaryngol, 2006; 126(9): 934-40

26. Skarżyński H., Lorens A., Piotrowska A., Anderson I.: Partial deafness cochlear implantation in children. Int J Pediatr Otorhinolaryngol, 2007; 71(9), 1407-13

27. Skarżyński H,. Lorens A., Piotrowska A., Anderson I.: Preservation of low frequency hearing in partial deafness cochlear implantation (PDCI) using the round window surgical approach. Acta Otolaryngol, 2007a; 127(1): 41-48

28. Skarżyński H., Lorens A., Matusiak M., i wsp.: Partial deafness treatment with the nucleus straight research array cochlear implant. Audiol Neurootol, 2012; 17(2): 82-91

29. Vermeire K., Anderson I., Flynn M., Ven de Heyning P.: The influence of different speech processorand hearing aid settings on speech perception outcomes in electric acoustic stimulation patients. Ear Hear, 2008; 29: 76-86

30. Von Ilberg C., Kiefer J., Tillein H. i wsp.: Electric-Acoustic Stimulation of the Auditory System. ORL, 1999; 61: 334-40

31. Zeng F.G., Popper A.N., Fay R.R.: Cochlear implants. Auditory Prostheses and Electric Hearing. Springer-Verlag New York, 2004 